\title{
FEBRIKID - AN AYURVEDA ANTIPYRETIC - A CLINICAL TRIAL
}

\section{DETROJA S ${ }^{1}$ AND RASKAR SC ${ }^{2 *}$}

1: PG Scholar; Dept. of Kaumarabhritya, Parul Institute of Ayurved, Parul University, Vadodara; Gujarat

2: Associate Professor; Dept. of Kaumarabhritya, Parul Institute of Ayurved, Parul

$$
\text { University, Vadodara; Gujarat }
$$

*Corresponding Author: Dr. Swapnil C Raskar: E Mail: neonatecare99@gmail.com

Received 12 ${ }^{\text {th }}$ Dec. 2021; Revised $14^{\text {th }}$ Jan. 2022; Accepted $7^{\text {th }}$ Feb. 2022; Available online $5^{\text {th }}$ March 2022

$$
\text { https://doi.org/10.31032/IJBPAS/2022/11.3.1079 }
$$

\begin{abstract}
Background: Fever is the very cardinal and primary symptoms in many diseases. It's the very initial symptoms force the patients to visit clinician. Safe and time tested antipyretics like paracetamol are present in market. But there is need of time and to find alternative safe and effective herbal antipyretics as there is increased frequency of illness and pandemic situation across the globe. In present clinical study an Ayurveda herbo-mineral tablet (Febrikid) was prepared and used as symptomatic antipyretic agent. Materials and Methods: A Febrikid tablets were prepared in Parul Ayuved Pharmacy Vadodara Gujarat and was used in patients having fever. 30 Patients were enrolled from all different hospitals of Vaodara city. Special case record proforma and Google Forms were used for collection of data. Results: Significant antipyretic activity of Febrikid was noted in $80 \%$ of the individual with average dose of 2 tablets (500mg each) in TDS. Statistically significant results were observed in reduction of fever spike and duration of fever. Discussion and Conclusion: Febrikid is the combination having the drugs with antipyretics, analgesic and antimicrobial, antioxidant and anti-inflammatory properties with significant antipyretics effect and can be used in day to day clinical Ayurveda practices.
\end{abstract}

Key words: Antipyretics, Ayurveda, Febrikid, Fever 


\section{INTRODUCTION:}

Fever is very primary clinical feature of most of illnesses and it is very primary sign that lead to individual for seeking the medical aid and forcing the physician to investigate the case. Ranging from the simplest common cold to severe most carcinomatous situation, fever is the important sign which can't be ignored. Fever causes the feeling of uneasiness and discomfort, along with loss of appetite, tastelessness, irritability as its cardinal subjective feeling. Apart from this increase in body temperature is alarming physiological sign which should be taken in account on priority basis. Therefore, to reduce the body temperature is the main aim of therapy while treating fever as disease or fever as symptom of other underlying disease. Reduction in body temperature is achieved with different mean in Allopathic medicine aiming mainly as antipyretic effect. Paracetamol, Ibuprofen, mefenamic acid, diclophenac sodium are different antipyretics are in used since long time, and this entire agent are found to be effective and safe in recommended doses. Though this agent reduces the body temperature readily, in many cases there is no effect of antipyretic pharmacological agent on pathology of underlying diseases and hence these drugs have only role in symptomatic relief of body temperature, pain etc.

On the contrary Ayurveda have large number of multiple drugs combinations known as Kashaya for treatment of fever. All the ingredients of different Kashaya act on the different systems and organs and help to treat or cure the pathogenesis of underlying disease and to reduce the body temperature as well. In Ayurveda fever is known as Jwara and classified in different types. Broadly Jwara has been classified on the basis of the Dosha responsible for it, for example Vataja Jwara, Pittaja Jwara, Kaphaja Jwara etc as different types. The treatment of these different Jwara varies according to involvement of Dosha casuing Jwara. Sharangdhara Samhita, one of the legendary ancient Ayurveda drug formulatory describe Guduchyadi Kashaya as a treatment of Jwara. In order to increase the efficacy and potential of medicine; Kashaya can be converted to Ghana Vati, which is highly effective and potent. With this logic to reduce the dose and to increase the efficacy and palatability Guduchyadi Kashaya Ghana Vati was selected for this clinical study. Gypsum well known calcium ore in medicinal use since ancient time and is used in different Vata-Kaphaja Vikara including fever. The 
gypsum is added in above mentioned

Guduchyadi Ghana Vati and "Febrikid"

tablet has made. In this study clinical study on antipyretic effect of Febrikid tablets is revealed.

Fever is the commonest presentation of many diseases of childhood and is of very primary or of utmost concern as children may have chances to get febrile convulsion as one of the deadly complication of fever in paediatric age group. Considering this early intervention for fever in children is highly essential. Febrikid tablets are also used in children with fever for this clinical study.

AIM:

- To evaluate the anti-pyretic effect of the Febrikid tablets as symptomatic treatment

\section{INCLUSIVE CRITERIA:}

- Temp between $99-104^{\circ} \mathrm{F}$.

Febrikid tablets is the herbo-mineral combination in which the Guduchyadi Kashaya from Ashtanga Hridaya Sutra Sthana was taken as the antipyretic medicine and Godanti (gypsum) Bhasma was added as mineral antipyretic to the combination to enhance its antipyretic effect. In order to reduce the dose of medicine and to improve its potency the Guduchyadi Kashaya was make in to Rasa kriya (Ghana Vati) and Godanti added to Ghana to make Febrikid tablet. All drug
- Fever of acute onset without any complications i.e. dehydration, convulsion, etc.

- Acute onset fever of 1 to 3 days.

- Patient of either sex suffering from fever of age 5-80 years.

- Children with parents who agree to participate and sign the informed consent.

\section{EXCLUSIVE CRITERIA:}

- Fever more than 3 days.

- Chronic fever associated with infective disorder.

- Any febrile condition of children requiring an immediate intervention depending of history and general condition at the point of examination as found by the investigators noninducible was be excluded from study.

\section{- MATERIALS AND METHODS:}

procured from the local market of the Vadodara city Gujarat and authenticed ib pharmacognosy department of Parul Ayurved Instittutue. The finished product was prepared in GMP certifed Parul Ayurveda Pharmacy of Parul University with following the SOP for Ghana Vati formation. The 30 patients/subjects with fever having 5 to 60 years of age were enrolled in this study in between September 2021 to December 2021. According to age, weight and spike of fever we have given 
Febrikid tablets in different amount to individual. Data collected with specially prepared case record form and Google forms. Data obtained were recorded in Microsoft Excel 2011 and all statistical analyses were performed with Graph Pad Prism software (version4.00). SPSS for Windows version 17.0, Chicago, USA, was also used for data analysis. Descriptive characteristics (mean and standard deviation) and percentage were performed for each parameter separately.

\section{OBSERVATION AND RESULTS:}

As trial was conducted in general, and hence subjects of all age groups are included in study, the lowest age limit was observed to 4 years while upper range of age was observed 55 years. Among which maximum number of patients are belongs to young adult age group (18-30 years).

\section{Types of Fever:}

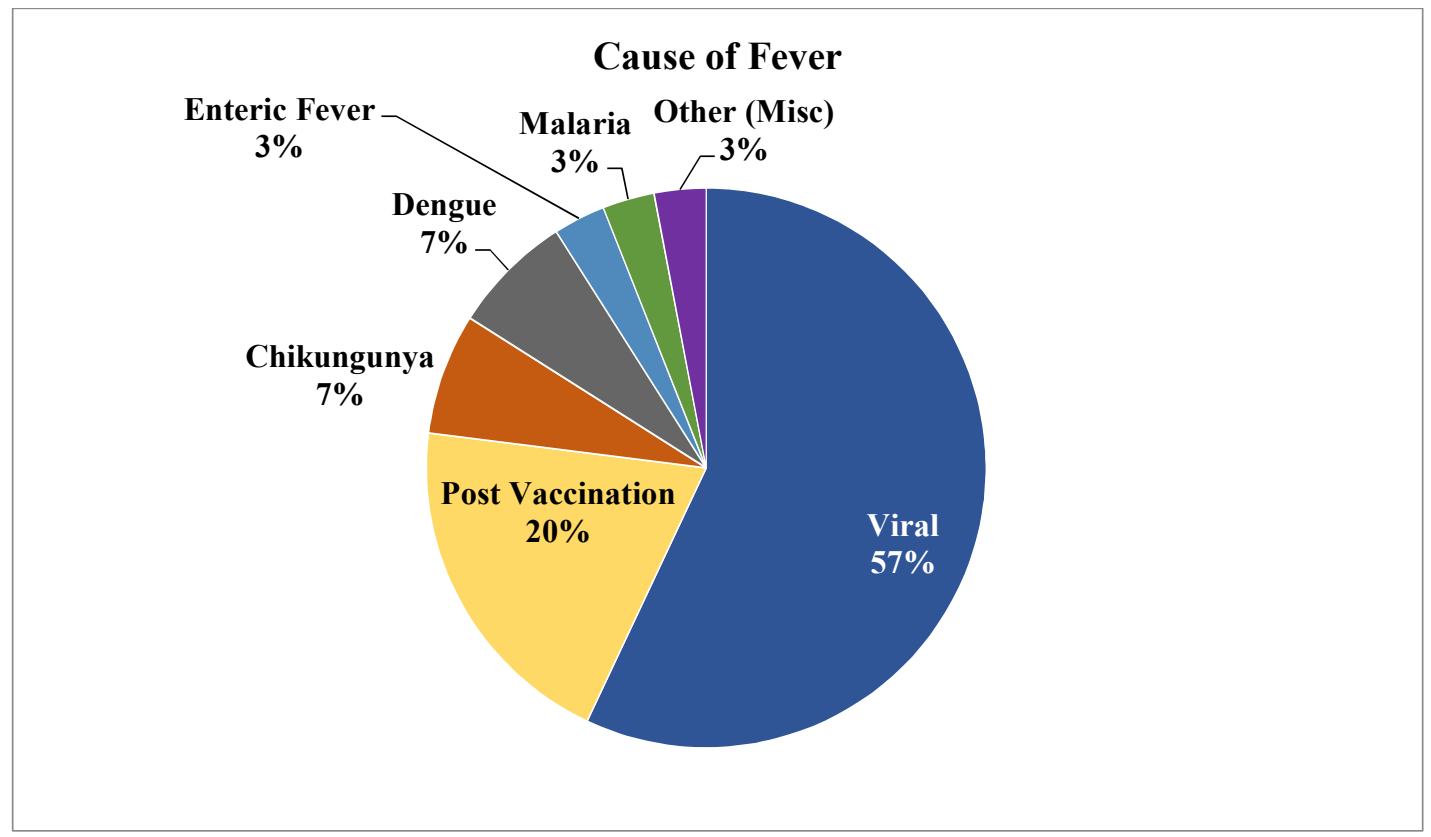

Graph No.1: Etiological factors for fever in $\mathbf{3 0}$ patients

From 30 patient $57 \%$ having viral fever and $20 \%$ are having post vaccination symptoms like fever, headache, and other are having dengue, Chikungunya, typhoid fever. 


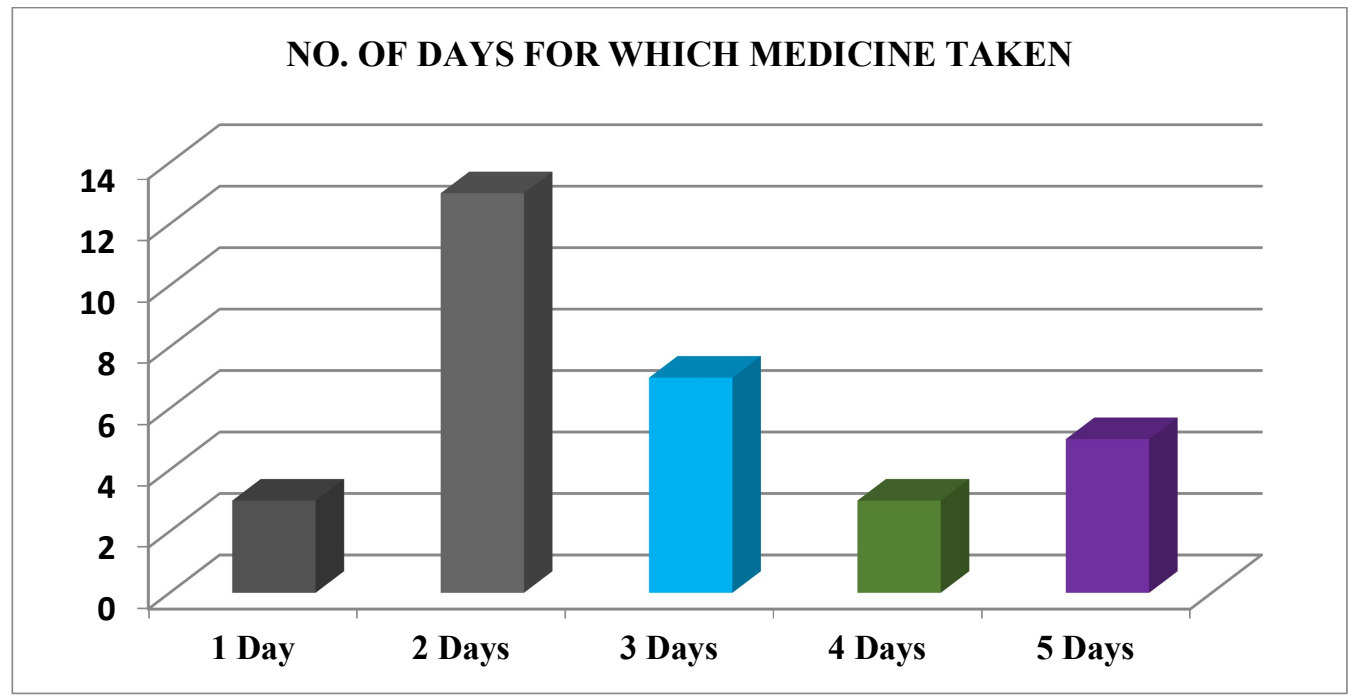

Graph No. 2: Number of days for which medicines taken by patients

Maximum $77 \%$ of the patients are taken febrikid tablet for 2-3 days to gets afebrile.

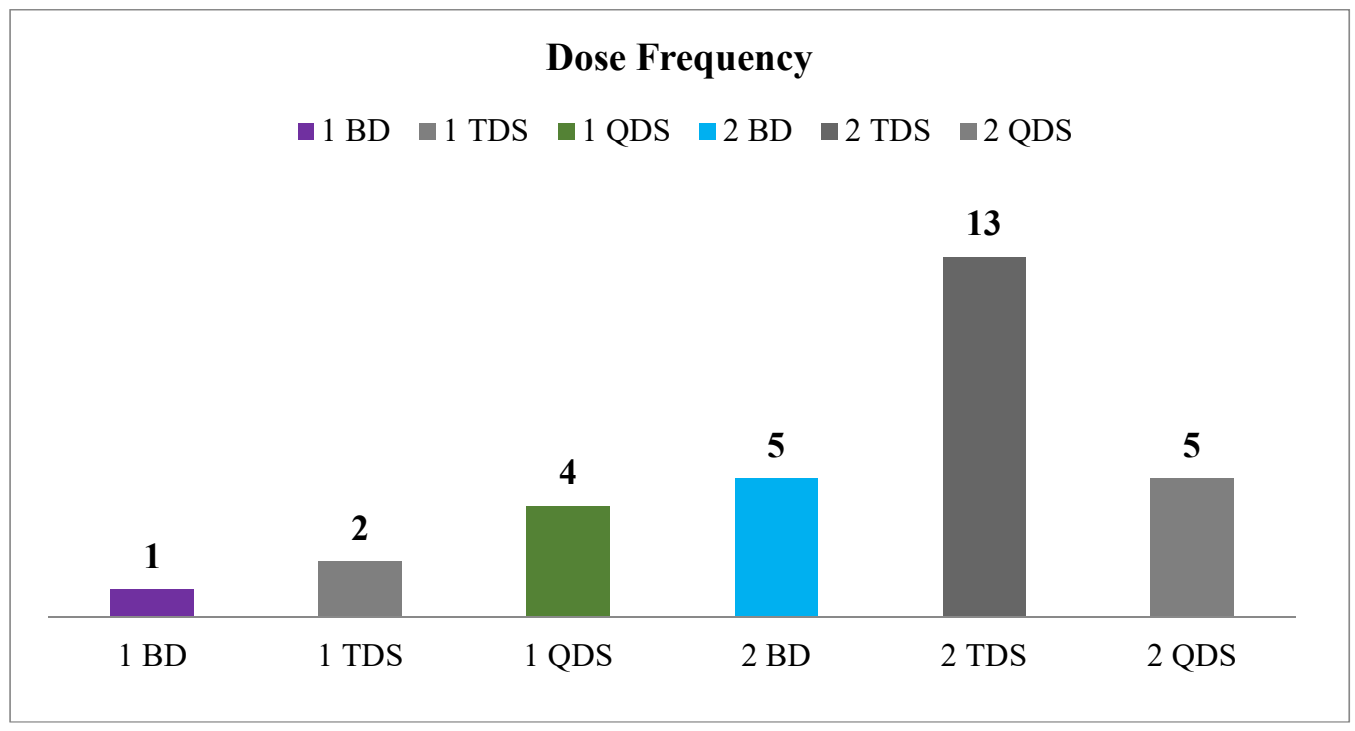

Graph No.3: Dose or frequency of administration of Febrikid tablets to 30 patients

Maximum patients (43\%) were optimum dose for antipyretics effect of observed the dose of 2 tablets of Febrikid Febrikid tablets. three times a day. It means 2 TDS is the 


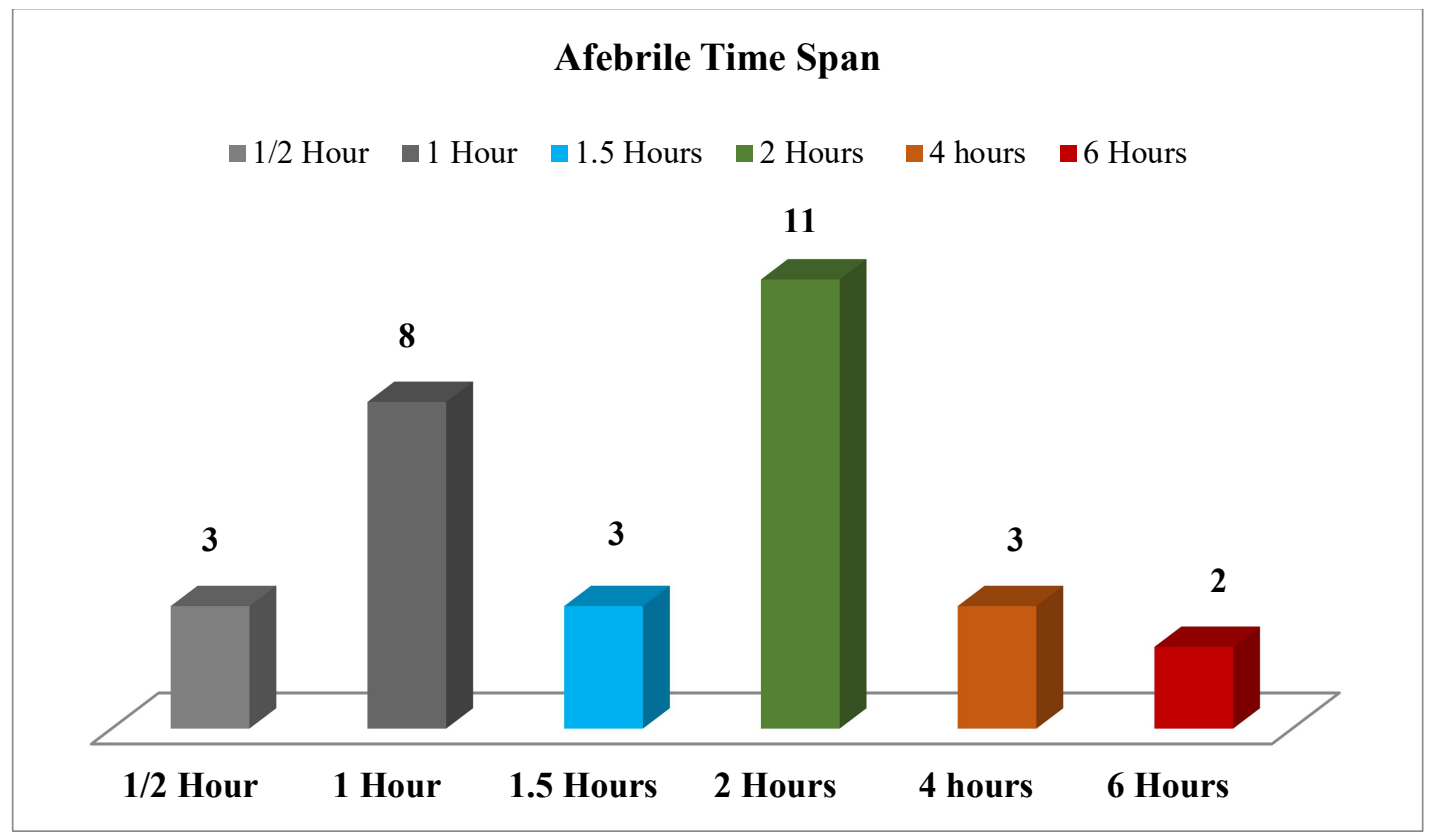

Graph No. 4: Time Span taken to get Afebrile by 30 Patients treated with febrikid

Maximum patients $(85 \%)$ get afebrile pyretic effect of the febrikid tablets as a before 2 hours suggest significant anti- symptomatic medicine for fever.

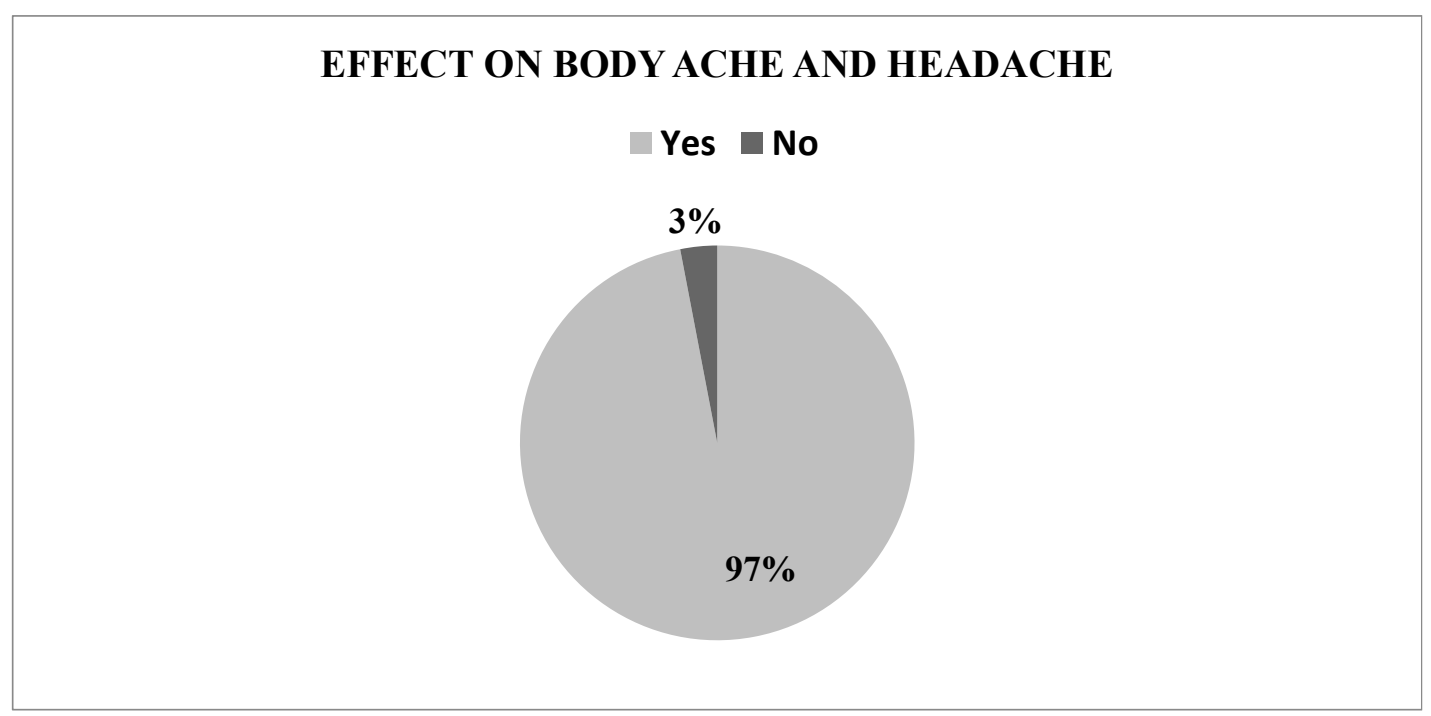

Graph No. 5: Effect on Headache and body ache

In 30 patient $96.7 \%$ patients get relief in headache and body ache along with fever 


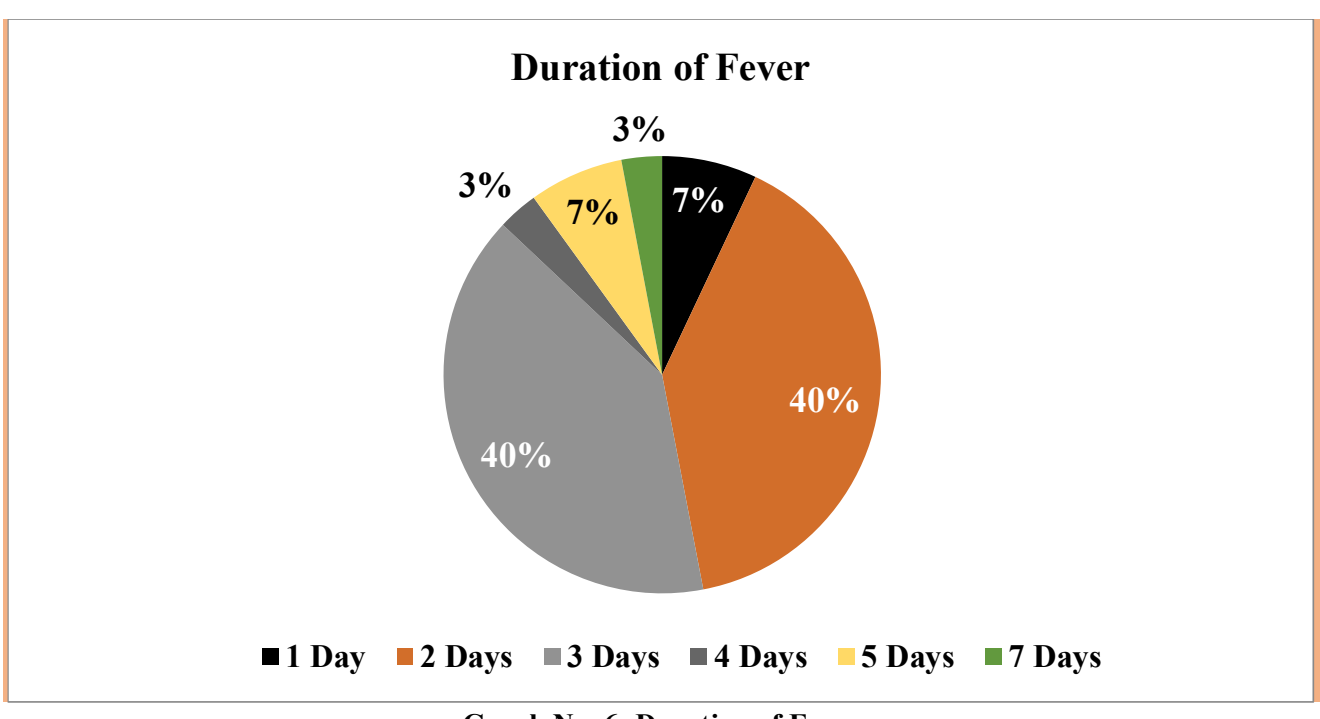

Graph No. 6: Duration of Fever

Duration of fever may vary according to type and cause of fever; out of 30 patient $40 \%$ have complaint fever of 1 and 2 days.

Table No.1: Number of fever spikes in 30 patients

\begin{tabular}{|c|c|c|}
\hline No of Spikes of fever in 24 hours & Number of Patients & Percentage \\
\hline$>6$ & 1 & $3.33 \%$ \\
\hline 6 & 1 & $3.33 \%$ \\
\hline 5 & 1 & $3.33 \%$ \\
\hline 4 & 8 & $26.67 \%$ \\
\hline 3 & 6 & $20 \%$ \\
\hline 2 & 12 & $40 \%$ \\
\hline 1 & 1 & $3.33 \%$ \\
\hline
\end{tabular}

Presentation of fever may vary according to type and cause of fever, and hence in present study there were difference in the spikes of fever and presentation of fever with associate complain.

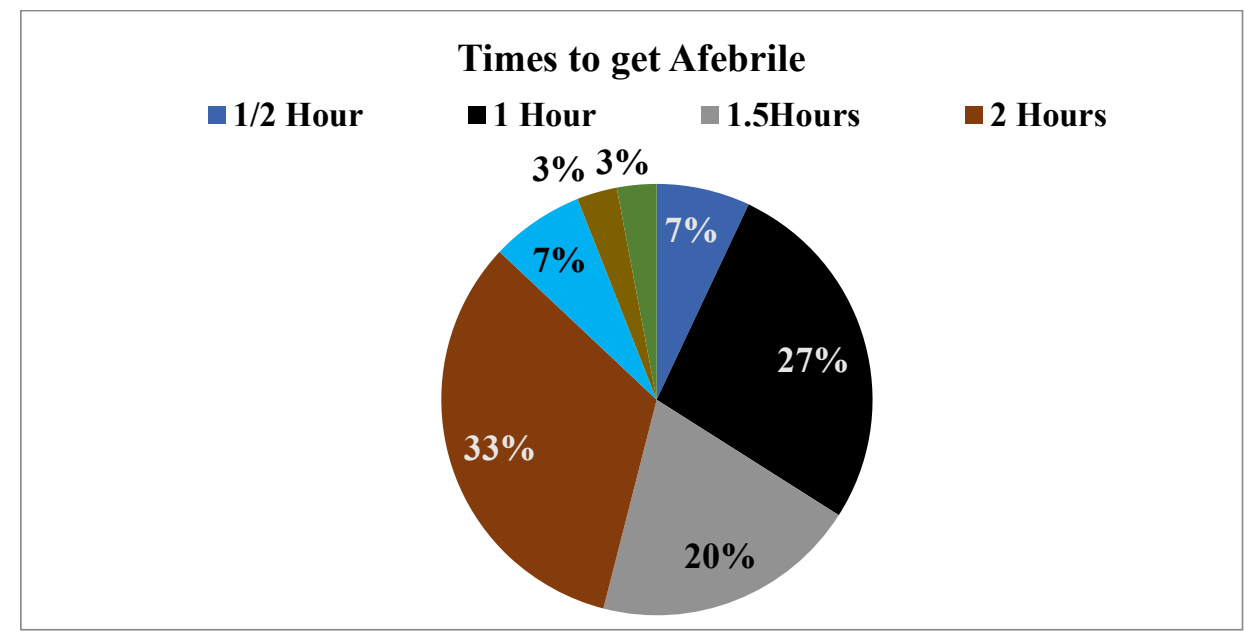

Graph No. 7: Time Span for getting Afebrile

In $80 \%$ of patients fever reduced within 2 hours; which suggest significant antipyretic effect of Febrikid tablets. 


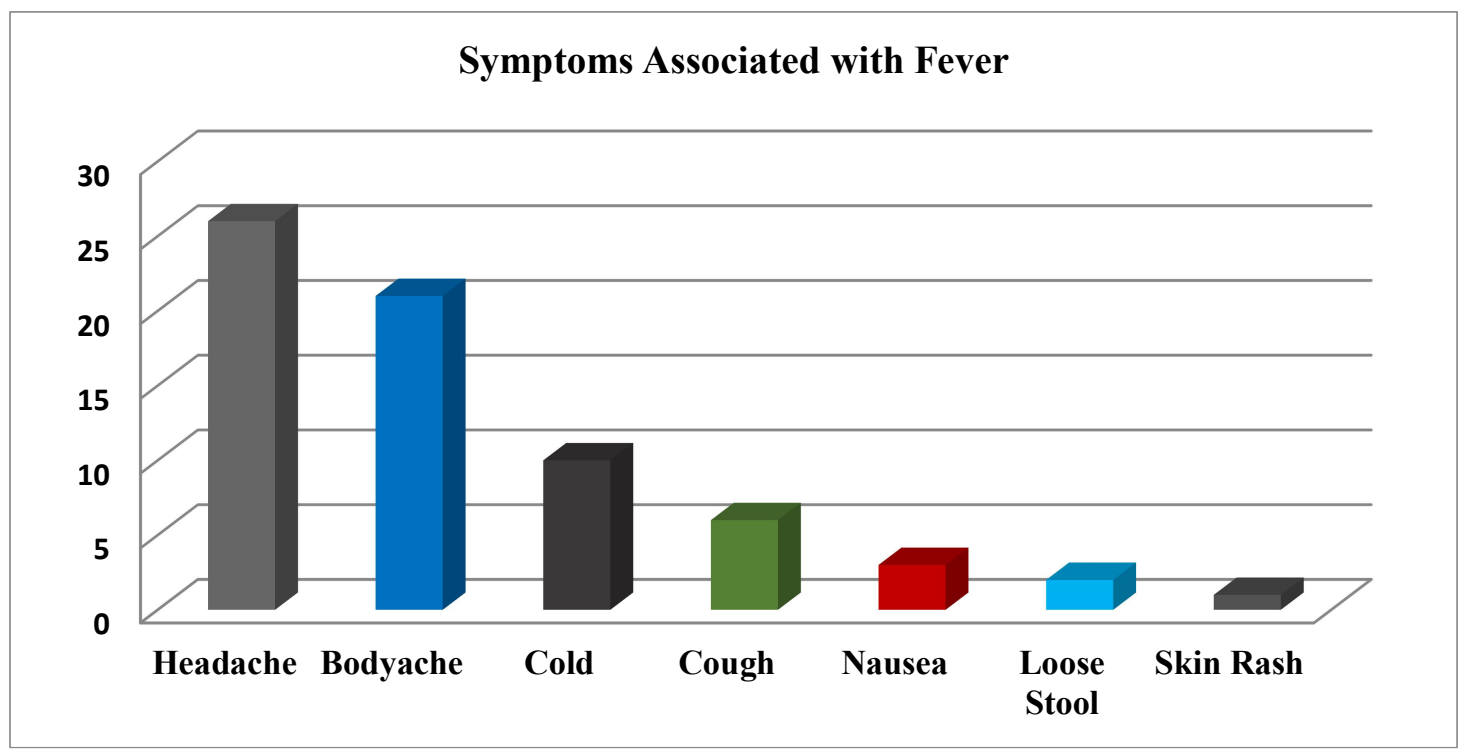

Graph No. 8: Symptoms associated with fever:

The entire 30 patient has co-symptoms like headache, body ache, cold, and cough. There is significant therapeutic effect of
Febrikid tablet on Bodyache and Head ache was observed.

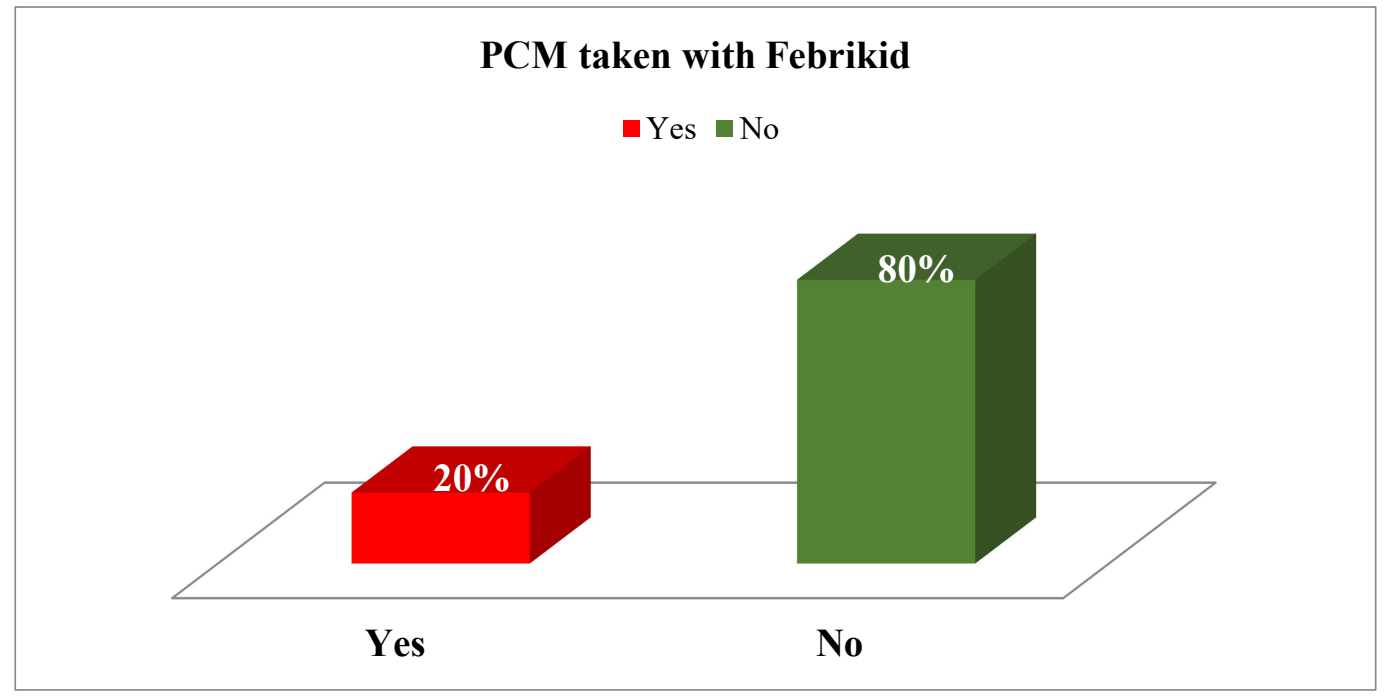

Graph No. 9: Antipyretics required in patients

Among the 30 patients treated with the Febrikid tablets maximum (80\%) patients get afebrile; while $20 \%$ patients required conventional antipyretics like Paracetamol or Ibuprofen.
DISCUSSION: There are different causes of fever and can be considered as infection, infestations, inflammation, infarctions and ischemia, infiltration, immunological, iatrogenic, idiopathic, 
inherited diseases, granulomatous diseases, endocrine disorders, Metabolic disorders. ${ }^{1}$ Though there is various causes the antipyretic medicines are universally used in conventional medicines along with the treatment of underlying disease pathology. Staphylococcus aureus is a major human pathogen that causes a wide range of clinical infections. It is a leading cause of bacteremia and infective endocarditis as well as osteoarticular, skin and soft tissue, pleuropulmonary, and device-related infections. $^{2}, \quad{ }^{3}$ In Ayurveda the management of fever is not merly symptomatic antipyretic but to treat the underlying pathology with DeepanaPachana-Langhana-Ushnodaka treatment and on this fundamental of Ayurveda treatmetnt of fever fbrikid tablets were made with the cluster of medicines having antipyretics, analgesic and antimicrobial, antioxidant and anti-inflammatory properties.

Some evidence based researches on the contents of febrikid tablets are enlisted in table below:

Table No.2: Chemical constituents and pharmaceutical action of the contents of febrikid tablets

\begin{tabular}{|c|c|c|}
\hline $\operatorname{Nimba}^{4}$ & Chemical Constituents & Action \\
\hline & $\begin{array}{c}\text { Margosic acid, Limonoids, Azadirachtin, } \\
\text { Azadiradione, nimbin, Salannin, } \\
\text { Stigmasterol, Nimbiol, Sugiol, a-terpinene } \\
\text { terpinen-4-ol, 4-cymene, } \\
\text { epoxyazadiradione and Vitamin E } \\
\text { Neem leaf glycoprotein (NLGP) } \\
\text { Proline } \\
\text { Ethanol Extracts of NL } \\
\text { Neem Enrich Yogurts (NEY) } \\
\text { Anti-pyretics } \\
\text { Anti-inflammatory }\end{array}$ & $\begin{array}{c}\text { Antihyperglycemic (blocking the inhibitory influences of } \\
\text { serotonin on insulin secretion mediated by glucose) } \\
\text { Antipyretic, Fungicidal, Antihistamine and Antiseptic Anti- } \\
\text { inflammatory (inhibitors of prostag-landin biosynthesis, and } \\
\text { endoperoxides and the enzymes like protein kinases and } \\
\text { phosphodiesterases and tumor necrosis factor alpha(TNF- } \alpha \text { ), } \\
\text { and by inhibiting pro-inflammatory cytokines like } \\
\text { Interleukins-IL), Anti-oxident } \\
\text { Immune-modulatory activity (modulating local and systemic } \\
\text { immunity) = } \\
\text { Treatment for neurodegenerative diseases like Alzheimer's } \\
\text { and Parkinson's disease, Type } 2 \text { Diabetes Mellitus and } \\
\text { Polycythemia } \\
\text { MrSA } \\
\text { Antibacterial activity against both Staphylococcus aureus and } \\
\text { Motent anti-oxidant in Diabetes and Hypertensive patient - by } \\
\text { inhibition of } \alpha \text {-amylase } \alpha \text {-glucoside, and angiotensin } \\
\text { converting enzyme. } \\
\text { Neem could interfere in the IL-1 - COX2 stimulation and } \\
\text { producing an antipyretic effect } \\
\text { Inhibition of cyclooxygenases } 1 \text { and } 2 \text { (COX1, COX2) }{ }^{7}\end{array}$ \\
\hline Guduchi $^{8}$ & $\begin{array}{l}\text { Arabinogalactan polysaccharide (G1-4A) } \\
\text { N-methyl-2-pyrrolidone, N- } \\
\text { formylannonain, 11-hydroxymustakone, } \\
\text { cordifolioside A, tinocordiside, syringin, } \\
\text { and magnoflorine }\end{array}$ & $\begin{array}{l}\text { A protective effect against lipopolysaccharide-induced } \\
\text { endotoxic shock by modulating cytokines and nitric oxide } \\
\text { excretion by murine macrophages and induces a non-specific } \\
\text { immune response. } \\
\text { Amplified presence of macrophages, T cells, and B cells, as } \\
\text { well as increased expression of anti-apoptotic genes in immune } \\
\text { cells. } \\
\text { Increases the production of nitric oxide from macrophages } \\
\text { and splenocytes and produces anticancer effect } \\
\text { Up regulate the cytokine IL-6, with subsequent events that } \\
\text { include activation of the inflammatory response and cytotoxic } \\
\text { T cells as well as differentiation of B cells } \\
\text { Activate human lymphocytes and downregulate the } \\
\text { production of inflammatory mediators } \\
\text { Attenuate ischemic brain damage via preventing ROS } \\
\text { production, with consequent amelioration of oxidative stress- } \\
\text { mediated cell injuries caused by oxygen/glucose deprivation } \\
\text { through direct effects and modulation of gene expression } \\
\text { Upregulation of lipid peroxide and catalase activity on the } \\
\text { erythrocyte membrane and downregulated SOD and GPX } \\
\text { activity }\end{array}$ \\
\hline
\end{tabular}




\begin{tabular}{|c|c|c|}
\hline & Anti-inflammatory & $\begin{array}{l}\text { Antioxidant ameliorative role against aflatoxin-induced } \\
\text { nephrotoxicity (free radical-scavenging activity against } \\
\text { hydroxyl radicals (OH), superoxide anion }(\mathrm{O}-) \text {, peroxynitrite } \\
\text { anion (ONOO-), and NO radicals) } \\
\text { Protective property against iron-induced lipid peroxidation in } \\
\text { brain homogenates } \\
\text { Scavenge ROS, downregulates TBARS levels and stimulates } \\
\text { the activity of SOD, GSH, catalase, glutathione S-transferase, } \\
\text { GPx, and glutathione reductase in the kidney } \\
\text { Decreased synthesis of proinflammatory cytokines, for } \\
\text { example, IL-1 } \beta \text {, IL-17, tumor necrosis factor- } \alpha \text {, and IL-17 }\end{array}$ \\
\hline $\begin{array}{lr}\begin{array}{l}\text { Wild } \\
\text { cherry }\end{array} & \begin{array}{r}\text { Himalayan } \\
\text { (Prunus }\end{array} \\
\text { cerasoides) } & \end{array}$ & $\begin{array}{l}\text { Methanolic Extracts } \\
\text { Antilithic, Spasmolytic } \\
\text { Antipyretic and tonic; Anti-inflammatory } \\
\text { Analgesic, Carminative, Expectorant, } \\
\text { Antispasmodic, febrifuge, antioxidant } \\
\text { and tonic }\end{array}$ & $\begin{array}{l}\text { Mild to moderate Antiplasmodial and Antimalarial activity } \\
\text { without any cytotoxic effects on mammalian cell lines } \\
\text { Antimalarial activity and validates its uses in traditional } \\
\text { medicines against protozoal diseases. }{ }^{10,11,12}\end{array}$ \\
\hline Raktachandana $^{13}$ & methanolic extract & $\begin{array}{l}\text { Anti-inflammatory, Analgesic and Antioxidant activities } \\
\text { Pterocarpus santalinus bark-wood powder in } 7 \mathrm{mg} / \mathrm{kg} \text { dose } \\
\text { showed significant anti-inflammatory and analgesic activity in } \\
\text { carrageenan induced inflammatory model in rats } \\
\text { The aqueous extract } 400 \mathrm{mg} / \mathrm{kg} \& 800 \mathrm{mg} / \mathrm{kg} \text { ) of heart wood of } \\
\text { P. santalinus possessed significant antipyretic activity }{ }^{14}\end{array}$ \\
\hline Dhanyaka & $\begin{array}{l}\text { Linalool and Linalyl acetate } \\
\text { 2-decenoic acid, E-11-tetradecenoic acid, } \\
\text { and capric acid }^{16}\end{array}$ & $\begin{array}{l}\text { Ulcer severity and area as well as the total colitis index, same } \\
\text { results indicating meaningful alleviation of colitis was } \\
\text { achieved after treatment with oral extract and essential oil. }{ }^{17} \\
\text { Coriander extract exhibited membrane stabilization effect by } \\
\text { inhibiting hypo tonicity } \\
\text { induced lysis of erythrocyte membrane }{ }^{18} \\
\text { Anti-inflammatory, Analgesic, and Antibacterial agent }{ }^{19} \\
\text { Antioxidant, Antidiabetic, Hepatoprotective, Antibacterial, } \\
\text { and Antifungal activities }\end{array}$ \\
\hline
\end{tabular}

\section{MODE OF ACTION:}

This medicine has antipyretic and analgesic effect. It is a combination of 6 drugs their individual effects are:

Table No.3: EBM at Glance for Febrikid tablets

\begin{tabular}{|c|c|c|c|}
\hline Name & Scientific name & $\begin{array}{c}\text { Pharmacological properties } \\
\text { Reported }\end{array}$ & Active chemical constituents \\
\hline Guduchi & Tinospora Cordifolia & $\begin{array}{l}\text { Antipyretic effect } \\
\text { Thermoregulatory }\end{array}$ & $\begin{array}{c}\text { Terpenoids, } \text { Alkaloids, } \\
\text { Berberine, } \\
\text { Berberine }\end{array}$ \\
\hline Nimba & Azadirachta Indica & $\begin{array}{c}\text { Antifungal } \\
\text { antiviral } \\
\text { antibacterial } \\
\text { immunomodulatory }\end{array}$ & $\begin{array}{c}\text { Nimbin, Nimbiol, } \\
\text { Azadirachtin }\end{array}$ \\
\hline Padmak & $\begin{array}{c}\text { Prunus Cerasoides D. } \\
\text { Don }\end{array}$ & $\begin{array}{c}\text { antiviral } \\
\text { antibacterial } \\
\text { anti-inflammatory }\end{array}$ & Flavonoids \\
\hline Dhanyak & Coriandram sativam & $\begin{array}{c}\text { Anti-inflammatory } \\
\text { antibacterial }\end{array}$ & Coriandrol, Tannins, Alkaloids \\
\hline Raktachandan & Pterocarpus Santalinus & $\begin{array}{l}\text { Anti-inflammatory } \\
\text { Antimicrobial }\end{array}$ & $\begin{array}{c}\text { Glycosides, } \\
\text { Colouring matter - Santalin, } \\
\text { Pterocarpin }\end{array}$ \\
\hline Godanti & Gypsum & - & $\mathrm{CaSO}_{4} 2 \mathrm{H}_{2} \mathrm{O}$ \\
\hline
\end{tabular}

GUDUCHI: antipyretic activity of

Guduchi Ghrita is established in albino rats in yeast induced fever ${ }^{20}$.
NIMBA: ethanol extract of Neem showed in vitro antibacterial activity against both Staphylococcus aureus and MRSA ${ }^{21}$ 
PADMAK: Klebsiella pneumoniae and Staphylococcus aureus were the most sensitive micro-organisms, respectively. Among the major phytoconstituents, flavonoids, diterpenes, and cardiac glycosides exhibited broad-spectrum antimicrobial activity $^{22}$

\section{RAKTACHANDANA: Pterocarpus}

Santalinus have been reported antiinflammatory, antioxidant, antidiabetic effect and also hepato-protective activity ${ }^{23}$

DHANYAKA: The phytochemical screening of Coriandrum sativum showed analgesic, antibacterial, hepatoprotective, anti-inflammatory effect ${ }^{24}$

GODANTI: The recent experimental finding suggests it as a very promising formulation for Peptic Ulcer Disease, Pyrexia of unknown origin and also very safe in a dose dependent manner ${ }^{25}$

In all the Febrikid is the combination having the drugs with antipyretics, analgesic and antimicrobial, antioxidant and antiinflammatory properties. Hence the drug show potent antipyretic effect and additionally combating the underlaying pathology of fever and therefore the combination shows additional advantage over the conventional antipyretics used and more research to prove its antipyretic effect is needed. CONCLUSION:

There is definite and potent antipyretic effect of the Febrikid tablets as a symptomatic relief for fever and further clinical evaluation of this combination is needed in complicated cases and in paediatric population.

\section{REFERENCE:}

${ }^{1}$ Swapnil CR, Jayesh Purohit; Text Book of Bala Roga: Section B, Chapter 10; Aupasargika Vyadhi (infectious diseases): Chaukhambha Vishvabharati Varanasi (Bharat); 2022 p.193194.

2 Tong SY, Davis JS, Eichenberger E, Holland TL, Fowler VG Jr. Staphylococcus aureus infections: epidemiology, pathophysiology, clinical manifestations, and management. Clin Microbiol Rev. 2015 Jul;28(3):603-61. doi: 10.1128/CMR.00134-14. PMID: 26016486; PMCID: PMC4451395

${ }^{3}$ Ashok BK, Ravishankar B, Prajapati PK, Bhat SD. Antipyretic activity of Guduchi Ghrita formulations in albino rats. Ayu. 2010 Jul;31(3):367-70 _ doi: 10.4103/09748520.77162. PMID: 22131741; PMCID: PMC3221073.

4 Alzohairy MA. Therapeutics Role of Azadirachta indica (Neem) and Their Active Constituents in Diseases Prevention and Treatment. Evid Based Complement Alternat Med. 2016;2016:7382506. doi: 10.1155/2016/7382506. Epub 2016 Mar 1. PMID: 27034694; PMCID: PMC4791507.

5 Parsaeimehr Ali, Yi-Feng Chen, Elmira Sargsyan, Chapter 12 - Bioactive Molecules of Herbal Extracts with Anti-Infective and Wound Healing Properties, Editor(s): Kateryna Kon, Mahendra Rai, Microbiology for Surgical 
Infections, Academic Press, 2014, Pages 205220

${ }^{6}$ Jose Francisco Islas, Ezeiza Acosta, Zuca GBuentello, Juan Luis Delgado-Gallegos, María Guadalupe Moreno Treviño, Bruno Escalante, Jorge E. Moreno-Cuevas, An overview of Neem (Azadirachta indica) and its potential impact on health, Journal of Functional Foods, Volume 74, Nov 2020, 104171

${ }^{7}$ Jose Francisco Islas, Ezeiza Acosta, Zuca GBuentello, Juan Luis Delgado-Gallegos, María Guadalupe Moreno-Treviño, Bruno Escalante, Jorge E. Moreno-Cuevas, An overview of Neem (Azadirachta indica) and its potential impact on health, Journal of Functional Foods, Volume 74, 2020,104171, ISSN 1756-4646, https://doi.org/10.1016/j.jff.2020.104171.(https: //www.sciencedirect.com/science/article/pii/S1 756464620303959)

8 Muhammad Saeed, Muhammad Naveed, Jakob Leskovec, Asgahr Ali kamboh, Ihsanullah Kakar, Kifayat Ullah, Fawwad Ahmad, Muhammad Sharif, Asif Javaid, Mubasher Rauf, Mohamed E. Abd El-Hack, Mervat A. Abdel Latif, Sun Chao, Using Guduchi (Tinospora cordifolia) as an ecofriendly feed supplement in human and poultry nutrition, Poultry Science, Volume 99, Issue 2, 2020, Pages 801-811, ISSN 0032-5791, https://doi.org/10.1016/j.psj.2019.10.051.

9 Arora DS, Mahajan H. In Vitro Evaluation and Statistical Optimization of Antimicrobial Activity of Prunus cerasoides Stem Bark. Appl Biochem Biotechnol. 2018 Mar;184(3):821837. doi: 10.1007/s12010-017-2571-8. Epub 2017 Sep 4. PMID: 28871479.
${ }^{10}$ Nino Joseph, Nishat Anjum, Y.C. Tripathi*, Prunus cerasoides D. Don: A Review on Its Ethnomedicinal Uses, Phytochemistry and Pharmacology; Int. J. Pharm. Sci. Rev. Res., 48(1), January - February 2018; Article No. 15, Pages: 62-69

11. Dhar ML, Dhar MM, Mehrotra DBN, Ray C, Screening of Indian plants for biological activity Part I, Ind J Exp Biol, 6: 1968, 232

${ }^{12}$ Blando F, Gerardi C, Nicoletti I, Sour cherry (Prunus cerasus L.) anthocyanins as ingredients for functional foods, J Biomed Biotechnol, (5), 2004, 253.

${ }^{13}$ Ratnamraju V, Dhande PP, Gupta AO and Vaz NS: Anti-inflammatory and analgesic activity of oral decoction of Pterocarpus santalinus bark wood powder in acute inflammation model. Int J Pharm Sci \& Res 2018; 9(10): 4368-72. doi: 10.13040/IJPSR.0975-8232.9(10).4368-72

${ }^{14} \mathrm{Cn}$, Shanti Vasudevan et al. "Antipyretic activity of aqueous extract of heart wood of Pterocarpus santalinus L. in yeast induced pyrexia." Journal of Pharmacognosy and Phytochemistry 8 (2019): 244-246.

15 Shreya Kothari, V.Vishnu Priya, R.GayathriInt: J. Pharm. Sci. Rev. Res., 43(2), March - April 2017; Article No. 12, Pages: 6870

16 Asgarpanah, Jinous \& N, Kazemivash. (2012). Phytochemistry, pharmacology and medicinal properties of Coriandrum sativum L. African journal of pharmacy and pharmacology. 6. 10.5897/AJPP12.901.

${ }^{17}$ Bahareh Heidari, Seyed Ebrahim Sajjadi, and Mohsen Minaiyan; Effect of Coriandrum 
sativum hydroalcoholic extract and its essential oil on acetic acid- induced acute colitis in rats: Avicenna J Phytomed. 2016 Mar-Apr; 6(2): 205-214. PMID: 27222834

18 Shreya Kothari, V.Vishnu Priya, R.GayathriInt: J. Pharm. Sci. Rev. Res., 43(2), March - April 2017; Article No. 12, Pages: 6870

19 Asgarpanah, Jinous \& N, Kazemivash. (2012). Phytochemistry, pharmacology and medicinal properties of Coriandrum sativum $\mathrm{L}$. African journal of pharmacy and pharmacology. 6. 10.5897/AJPP12.901.

${ }^{20}$ BK Ashok, B Ravishankar, P K Prajapati, Savitha D Bhat, Antipyretic activity of Guduchi Ghrita formulations in albino rats, Ayu2010, July-Sep; 31(3): 367-370. PMID: 22131741.

${ }^{21}$ Sarmiento W. C., Maramba C. C., Gonzales M. L. M. An in vitro study on the antibacterial effect of neem (Azadirachta indica) leaf extracts on methicillin-sensitive and methicillin-resistant Staphylococcus aureus. PIDSP Journal. 2011;12(1):40-45.

${ }^{22}$ Daljit Singh Arora,Major Phytoconstituents of Prunus cerasoides Responsible for Antimicrobial and Antibiofilm Potential Against Some Reference Strains of Pathogenic Bacteria and Clinical Isolates ofMRSA, applbiochembiotechnol,2019 Aug;188(4):11851204.

${ }^{23}$ SaradammaBulle, Hymavathi Reddyvari, Varadacharyulu Nallanchakravarthula, and Damodara Reddy Vaddi Therapeutic Potential of Pterocarpus santalinus L.: An Update. Pharmacogn Rev.

2016 Jan-Jun; 10(19): 43-49.
${ }^{24}$ Prof Dr Ali Esmail Al-SnafiA review on chemical constituents and pharmacological activities

of Coriandrum sativum, IOSR Journal Of Pharmacy,Volume 6, Issue 7 Version. 3 (July 2016), PP. 17-42

${ }^{25}$ Sharma Arun, Mitra Shuchi, Sharma KC, Yadav Yadevendra Updated Overview On Godanti Bhasma (An Ayurvedic Formulation Of Gypsum) unique journal of ayurvedic and herbal medicines UJAHM 2019, 07 (04): Page 19-26 